\title{
SCHWA, SYLLABLES, AND EXTRAMETRICALITY IN DUTCH
}

\author{
RENÉ KAGER and WIM ZONNEVELD
}

Most theories of modern phonology now seem to recognize that words consist of concatenations of syllables, as in (1), where each separate syllable conforms to the syllable restrictions of the language, be they linear, hierarchical, filterlike, template-like, or what have you. Furthermore, some models, such as the metrical phonology model adopted here, allow for larger possibilities at the left and right word-edges in the form of extrasyllabic elements, such as the final dentals of Herbst 'autumn' in German (Halle and Vergnaud 1980:95, after Haugen 1956). Schematically:

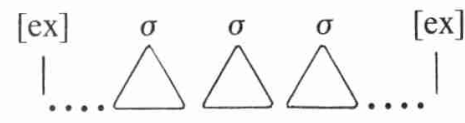

Thus, words are concatenations of "possible syllables", while extrasyllabic elements are subject to the probably universal condition that they appear at the edges of relevant domains; see also Harris (1983) on the Spanish syllable and similar work by Hayes (1982) on English stress.

Taking this concatenative view of syllable structure as our point of departure, we discuss in this paper a body of data from Dutch, which concern the situation depicted in (2). We will discuss the syllabic and metrical possibilities, including sonority and stress, of the right-hand word-edge containing and preceding schwa:

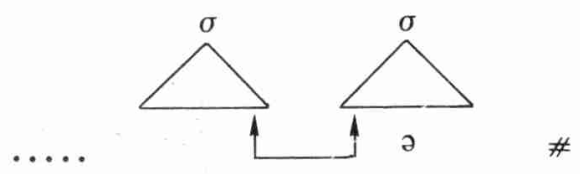

The behavior of schwa in Dutch is the subject of a lively debate in phonological analyses of the language, and our specific purpose here will be to show how the various aspects of its behavior can be correlated within the metrical syllabic and accentual framework.

\footnotetext{
*This paper was read in a preliminary version at the Leiden Non-Linear Phonology Meeting of May 3, 1985. We are grateful to the participants for useful comments. In particular, we would like to thank first and foremost Mieke Trommelen, for continuously reminding us of the relevant data, and Kees-Jan Backhuys, Egon Berendsen, Wim de Haas, Jan Nijen Twilhaar, Ellis Visch, and two anonymous referees for critical notes on previous versions of the analysis presented here.
} 
A number of further assumptions are in the background of our discussion. First, let us for clarity's sake repeat the cliché that the phenomenon of syllable division will be seen here as universal to the largest extent possible, and languageparticular only if required. This implies that we will not be concerned here with the syllable division of typically derived examples like those in (3) from Dutch, since they can be syllabified mechanically by universal principles of maximal onset, sonority, and sensitivity of syllabification to morphological domains in derived words.

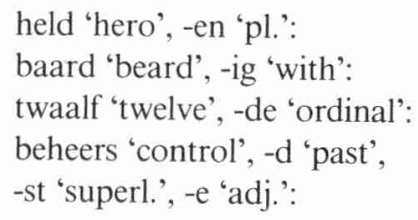

beheersd-ste 'most controlled'

The first three examples of (3) show the perfectly plausible interaction between the maximal onset principle and the sonority hierarchy, which together cannot provide a syllabification other than the one indicated. The fourth shows how morphological structure comes into play in ambiguous cases. Thus, a framework which takes derived structure as the input for syllabification appears on the one hand to disregard the independent contents of universal syllabic theory, while on the other it leads one to posit as regular, for a language such as Dutch, as many as five language-particular rime positions (h-eersd in the final example of (3)). Such a framework has been put forward recently for instance in Van der Hulst (1984), who proposes (p. 66)) that "[t]he set of syllables that occur in underived and uncompounded stems is a proper subset of the set of syllables that occur in (complex) words. By characterizing the larger set we characterize the smaller set as well." He then goes on to develop an account which not only leaves the subset undefined, but also suffers from the disadvantages noted above. More promising seems to us the position taken in Trommelen (1983) for Dutch, who assumes that the syllabification of all derived structure is governed by the universal principles accounting for the data in (3). This means that the interesting language-particular action takes place in underived structure (see also Hyman 1985:2), where we will have to account for two types of data, typically relating to syllable breaks in consonant clusters, and the quantitative contents of syllables. As regards the former, (4a) below shows that word-initial clusters are not automatically internal syllableinitial clusters as well; and, as shown in (4b), there are restrictions on the sheer number of segments allowed in a syllable, especially, in this case, in the rime.

$\begin{array}{clllllll}\text { a. sloom } & \text { 'dreary' } & \text { os-lo } & \text { 'Oslo' } & \text { kloof } & \text { 'precipice' } & \text { cy-cloop } & \text { 'cyclops' } \\ \text { slaap } & \text { 'sleep' } & \text { is-lam } & \text { 'Islam' } & \text { klier } & \text { 'gland' } & \text { e-clips } & \text { 'eclipse' } \\ \text { kneed } & \text { 'knead' } & \text { ac-né } & \text { 'acne' } & \text { praat } & \text { 'talk' } & \text { le-pra } & \text { 'leprosy' } \\ \text { knie } & \text { 'knee' } & \text { pic-nic } & & \text { prei } & \text { 'leek' } & \text { lam-prei } & \text { 'lamprey' } \\ & & & & & & \\ \text { b. os-lo } & * \text { oos-lo } & \text { tem-po 'speed' } & \text { *teem-po } & & & \\ \text { ac-né } & \text { *aac-né } & \text { sal-to } & \text { 'somersault' } & \text { *saal-to } & & & \end{array}$


One of the tasks of our theory of the (Dutch) syllable will therefore be to account for the facts in (4).

Second, we will say that the underlying syllable division will equal the phonetic or intuitive syllable division unless there are compelling reasons, say from alternations or distributional patterns, to deviate from it. Again, this reflects the usual generative practice of saying that minimal pairs like graat 'fish-bone' and graad 'degree' (both [t] in FINAL-DEVOICING Dutch) differ in their underlying forms because their plurals graten and graden differ, but this time applied to syllable structure. So when we propose, as we will do below, underlying or phonological syllabifications that differ clearly from surface facts or surface intuitions, implicit in our approach will be the assumption of "late", or "phonetic", or "post-cyclic" resyllabification. In the ideal case, which we think holds to a considerable degree, this resyllabification will boil down precisely to the principles underlying (3).

We now turn to the main body of this paper, which deals with three areas of investigation with respect to the representation under (2). We will discuss a. a number of filters on Dutch syllable structure defining syllable-bound collocational restrictions; $b$. a number of distributional facts regarding the occurrence of relatively long or heavy rimes, in relation to syllabic sonority; and $c$. properties of Dutch stress assignment, especially with respect to the behavior of schwa. We will tackle these issues in this order.

\section{FILTERS}

Consider the four restrictions in (5) holding in Dutch on the occurrence of $r, h$, and $\eta$.

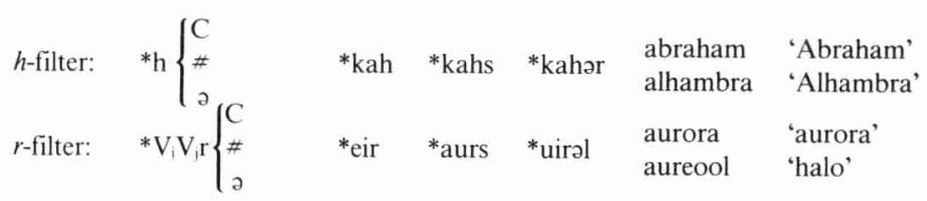

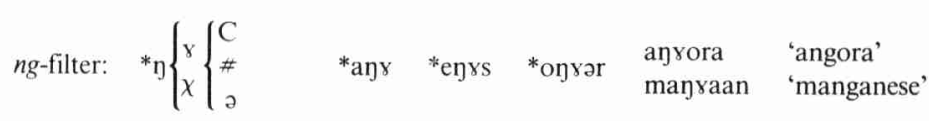

$$
\begin{aligned}
& \text { ฤ-filter: } \quad * \eta \mathrm{V} \text { (for } \mathrm{V} \neq \mathrm{a} \text { ) } \quad \sqrt{ } \text { rin 'ring' bank 'bank' enal 'angel' } * \text { anora }
\end{aligned}
$$

The first of these is a well-known restriction on the occurrence of $h$, which may occur, in effect, before vowels only, but not before schwa. The second is a similar restriction on the occurrence of post-diphthongal $r$ (post-au $r$ in particular). The third and the fourth restrictions follow from the analysis of $n g[\mathrm{y}]$ in Dutch as an underlying velar nasal rather than a cluster, a position defended in several places in the recent literature (for an overview see Trommelen 1983:ch.5). The $n g$-filter excludes the cluster from all positions where it occurs in the same syllable as well as from the pre-schwa position; the $\mathrm{n}$-filter accounts for the complementary distribution of the velar nasal. 
It is our specific purpose to explain by our analysis below the curious restrictions mentioned in these filters between braces and parentheses, i.e. the occurrences of consonant (C), boundary (\#), and schwa (ə) in the first three filters, and the non-schwa restriction in the fourth. Notice, however, that the occurrence of $\mathrm{C}$ and \# in the first three suggests syllable sensitivity for these restrictions but, on the other hand, the intuitive syllabifications of *ka-hor and abra-ham, *ui-rəl and au-rora, and *an-yər and an-yora is the same in each case; yet the distributional facts do not fall in line with these intuitive syllabifications. Put slightly differently, generally speaking we know why C behaves like a word boundary, because often the syllable break lies before $\mathrm{C}$, but now we would like to know why schwa behaves like a word boundary as well, and this is what we try to explain below.

\section{DISTRIBUTIONAL FACTS}

\subsection{Heavy rimes}

For further distributional facts that shed light on our discussion, first consider the data in (6).

$\begin{array}{lllllll}\text { lust } & \text { 'desire' } & \text { las-ter } & \text { 'slander' } & \text { pas-ta } & \text { 'paste' } & \text { *lust-ko } \\ \text { disk } & \text { 'disc' } & \text { mas-ker } & \text { 'mask' } & \text { es-kimo } & \text { 'Eskimo' } & \text { *ask-mer } \\ \text { ramp } & \text { 'disaster' } & \text { dom-per } & \text { 'damper' } & \text { kam-pong } & \text { 'kampong' } & \text { *lamp-tong } \\ \text { darm 'intestine' } & \text { mor-mel } & \text { 'freak' } & \text { mar-mot } & \text { 'marmot' } & \text { *darm-pol } \\ \text { ze:m 'shammy' } & \text { ze:-mel } & \text { 'bran' } & \text { ka:-meel } & \text { 'camel' } & \text { *te:m-po } \\ \text { ta:k } & \text { 'task' } & \text { be:-ker } & \text { 'cup' } & \text { ci:-cloop } & \text { 'cyclops' } & \text { *pa:k-tal }\end{array}$

These data show a number of things about the prevailing patterns of Dutch syllable structure, of which the following are presently most important: Dutch rimes have only two positions; the difference between schwa and full vowels does not influence the shape of the preceding rime in this respect; and wordfinal rimes have an additional (consonantal) position. The simplest view of Dutch syllable structure that follows from these observations is that of (7):

$$
]_{\text {Onset }}[\mathrm{X} \text { X }]_{\text {Rime }}[\mathrm{C}]_{\text {App }}
$$

Although our main concern in this paper will not be with the onset of Dutch syllables, we note that we adopt here the relatively constrained view of it proposed in Trommelen (1983), who allows only [C(L)], where L is a liquid (subject to further filters). Data such as those in (8) illustrate the positive effect of this constraint:

$$
\begin{array}{llll}
\text { ci:-cloop } & \text { 'Cyclops' } & \text { ma:-kreel } & \text { 'mackerel' } \\
\text { fol-klore } & \text { 'folklore' } & \text { pa:-prika } & \text { 'pepper' } \\
\text { ta:-blet } & \text { 'tablet' } & \text { ze:-bra } & \text { 'zebra' } \\
\text { i:-glo } & \text { 'igloo' } & \text { ma:-tras } & \text { 'mattress' }
\end{array}
$$




$\begin{array}{llll}\text { sja:-bloon } & \text { 'stencil' } & \text { som-brero } & \text { 'sombrero' } \\ \text { pam-flet } & \text { 'pamphlet' } & \text { pel-grim } & \text { 'pilgrim' } \\ \text { es-planade } & \text { 'esplanade' } & \text { man-dril } & \text { 'mandrill' } \\ \text { li:-vrei } & \text { 'livery' } & \text { oc-trooi } & \text { 'patent' }\end{array}$

On the negative side, nasals are banned from appearing in second position, as in (9):

$\begin{array}{llll}\text { jas-mijn } & \text { 'jasmin' } & \text { et-na } & \text { 'etna' } \\ \text { pris-ma } & \text { 'prism' } & \text { ac-né } & \text { 'acne' } \\ \text { schis-ma } & \text { 'schism' } & \text { pic-nic } & \text { 'picnic' } \\ \text { kos-mos } & \text { 'cosmos' } & \text { mag-neet } & \text { 'magnet' } \\ \text { mag-ma } & \text { 'magma' } & \text { mag-nolia } & \text { 'magnolia' } \\ \text { pig-mee } & \text { 'pygmy' } & \text { ag-naat } & \text { 'agnate' }\end{array}$

The possibilities are constrained further by specific filters against $* t l-,{ }^{*} s l$, and so on:

$\begin{array}{llll}\text { at-las } & \text { 'atlas' } & \text { is-lam } & \text { 'Islam' } \\ \text { at-leet } & \text { 'athlete' } & \text { os-lo } & \text { 'Oslo' } \\ \text { bet-lehem } & \text { 'Bethlehem' } & \text { mos-lim } & \text { 'moslem' }\end{array}$

This analysis accounts straightforwardly for the facts under (4), with the understanding that the analysis interacts with the notion of extrasyllabicity mentioned in the introduction. Recall that one of the most interesting constraints on this notion is its hypothesized occurrence on the edges of relevant domains only: it is precisely there that (7) contains its "extrametrical appendix", and it is precisely this restriction that accounts for the difference between the leftand right-hand columns of (4a). If left-hand $s$ is always extrasyllabic in Dutch, and initial $k$ is always extrasyllabic before $n$ (or nasals in general), we account both for the occurrence of knie alongside the internal syllabification of $a c$ -

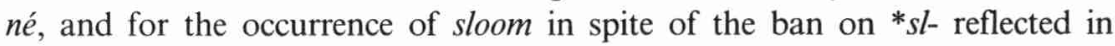
os-lo versus ci:-cloop and le:-pra.

As for the rime, the restriction to "two positions only" accounts for the data under (4b), repeated in the rightmost column of (6). No doubt the fact that the leftmost position of the rime is always occupied by a vowel follows from universal considerations, while the rightmost position appears simply to be free: it may be a vowel as second half of a long vowel, it may be the second half of a diphthong (which pattern with long vowels in Dutch; see Zonneveld and Trommelen 1980), and it may be a sonorant or an obstruent consonant, as in (8) and (9). Especially with regard to the latter we differ from Trommelen (1983), who has an XX-rime if a sonorant occupies second position, but allows $\mathrm{XXX}$ if there is an obstruent in third position (pamflet, plank-ton). Below we will review the evidence which led her to this proposal, indicating that there is no reason to differentiate between sonorants and obstruents in this respect, and concluding that the facts support our bipositional rime. 
Finally, (6) shows us that word-finally, as noted, the syllabic possibilities are more elaborate than word-internally. In principle, a consonant may be freely added to an XX-rime, creating a relatively heavy rime in this position. This is expressed in (7) by the addition of a consonantal right-hand appendix (terminology taken from Halle and Vergnaud 1980), at the right-hand periphery.

Given this, consider the facts in (11).

$\begin{array}{llllll}\text { lijst } & \text { 'list' } & \text { lijs-ter } & \text { 'thrush' } & \text { *eesk } & \text { *ees-ker } \\ \text { borst } & \text { 'breast' } & \text { bors-tel } & \text { 'brush' } & \text { *goesp } & \text { *goes-pel } \\ \text { koest } & \text { 'timid' } & \text { koes-ter } & \text { 'cherish' } & \text { *laamp } & \text { *laam-per } \\ \text { worst } & \text { 'sausage' } & \text { wors-tel } & \text { 'wrestle' } & \text { *daarm } & \text { *daar-mel }\end{array}$

So far, all of (11) is excluded by (7): words such as lijst and borst are excluded because their rimes exceed the upper limit of three imposed by (7) wordfinally; words such as lijster and borstel are excluded because there is simply no internal syllable division that conforms simultaneously to the bipositional rime requirement and the $\mathrm{C}(\mathrm{L})$ onset condition. However, typical for the data in (11) are two observations: they have VX before dental obstruent clusters word-finally (left-hand column), or they have VX word-internally before dental obstruents followed by schwa. Further data illustrating these two classes are those in (12):

$\begin{array}{llll}\text { be:st } & \text { 'beast' } & \text { he:ster } & \text { 'shrub' } \\ \text { fi:ts } & \text { 'bicycle' } & \text { schni:tzel } & \text { 'scallop' } \\ \text { puist } & \text { 'pimple' } & \text { bu:ste } & \text { 'breast' } \\ \text { beits 'mordant' } & \text { bijster } & \text { 'very' } \\ \text { fonds 'fund' } & \text { venster } & \text { 'window' } \\ \text { rijst } & \text { 'rice' } & \text { glinster } & \text { 'glitter' } \\ \text { ha:st 'hurry' } & \text { hamster 'hamster' } \\ \text { hulst 'holly' } & \text { holster 'holster' }\end{array}$

Of course, this implies neither that if schwa follows dentals, the preceding rime must be overlong, nor that schwa can only follow dentals. Thus, examples like las-ter and mas-ker from (6) can be extended with those in (13).

$\begin{array}{llll}\text { kas-te } & \text { 'caste' } & \text { has-pel } & \text { 'reel' } \\ \text { dis-tel } & \text { 'thistle' } & \text { ok-sel } & \text { 'armpit' } \\ \text { ves-te } & \text { 'stronghold' } & \text { kwis-pel } & \text { 'wag' } \\ \text { ripos-te } & \text { 'riposte' } & \text { sec-te } & \text { 'sect' } \\ \text { met-sel } & \text { 'build' } & \text { scep-ter } & \text { 'scepter' } \\ \text { knut-sel } & \text { 'potter' } & \text { ach-ter } & \text { 'behind' }\end{array}$

The data do imply, however, that if a full vowel follows a cluster, the preceding vowel must be short, since our extra possibilities are bestowed upon schwa only: 
(14)

$\begin{array}{llll}\text { pas-ta } & \text { 'paste' } & \text { mos-kee } & \text { 'mosque' } \\ \text { kas-teel } & \text { 'castle' } & \text { es-kimo } & \text { 'Eskimo' } \\ \text { swas-tika } & \text { 'swaktika' } & \text { mas-cotte } & \text { 'mascot' } \\ \text { kas-tijden } & \text { 'chastise' } & \text { wod-ka } & \text { 'vodka' } \\ \text { hos-tie } & \text { 'host' } & \text { nek-tar } & \text { 'nectar' } \\ \text { mus-tang } & \text { 'mustang' } & \text { ec-zeem } & \text { 'eczema' } \\ \text { fat-soen } & \text { 'decency' } & \text { rep-tiel } & \text { 'reptile' } \\ \text { mes-ties } & \text { 'mestizo' } & \text { rhap-sodie } & \text { 'rhapsody' }\end{array}$

(14) shows the validity of this generalization for internal obstruent clusters, but precisely the same holds, of course, if the internal cluster is fully sonorant, or a sonorant followed by an obstruent, as in (15).

$\begin{array}{llll}\text { kal-koen } & \text { 'turkey' } & \text { al-manak 'almanac' } \\ \text { or-chidee } & \text { 'orchid' } & \text { bil-jet } & \text { 'ticket' } \\ \text { aor-ta } & \text { 'aorta' } & \text { gal-joen 'galleon' } \\ \text { gam-biet } & \text { 'gambit' } & \text { for-nuis 'furnace' } \\ \text { en-zym } & \text { 'enzyme' } & \text { for-mule 'formula' } \\ \text { man-gaan } & \text { 'manganese' } & \text { kar-wats 'horsewhip' } \\ \text { ran-cune } & \text { 'rancor' } & \text { am-nestie 'amnesty' }\end{array}$

The only context where our analysis predicts that VX may precede a cluster (before a full vowel in the next syllable) occurs when the cluster is of the CL shape allowed by the onset template. The data provided under (8) corroborate this prediction: ta:-blet, som-brero, and so on. Thus, the proper generalization as regards excessive rime length appears to boil down to the following observation:

(16) Excessive rime weight is allowed before dental obstruents (-st, - $t s)$ wordfinally, and if schwa follows (-st-ə, -ts-ə).

Or, conversely, a syllable with schwa may follow any syllable with a bipositional rime, but also those syllables occurring only word-finally otherwise. Thus, (7) must be extended to (17) in order to capture generalization (16); we add illustrations.

$$
\begin{aligned}
& \ldots .[\mathrm{X} \mathrm{X}]_{\text {Rime }} \quad \mathrm{App}_{2} \quad \mathrm{App}_{2}
\end{aligned}
$$

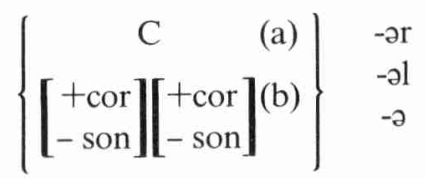

$\begin{array}{llllll}z & e & e & & & \text { 'sea' } \\ z & e & e & m & & \text { 'shammy' } \\ z & e & e & m & \text { ol } & \text { 'bran' } \\ b & e & e & \text { s t } & & \text { 'beast' } \\ h & \text { e } & \text { e } & \text { s t } & \text { or } & \text { 'shrub' }\end{array}$


This template is a first attempt to capture the empirical observation above about the co-occurrence restrictions of Dutch heavy rimes and the type of vowel following. Below we will refine it on the basis of further observations, but in the meantime consider the following minimal pairs or near-minimal pairs, which are all intended to lend credence to the view that (17) means to express: schwa-initials (our $\mathrm{App}_{2}$ ) follow "existing words".

$\begin{array}{llll}\text { lui } & \text { 'lazy' } & \text { lui-ər } & \text { 'napkin' } \\ \text { stom } & \text { 'stupid' } & \text { stomm-əl } & \begin{array}{l}\text { 'clatter' } \\ \text { lek }\end{array} \\ \text { 'leaky' } & \text { lekk-ər } & \text { 'delicious' } \\ \text { zo:-m } & \text { 'seam' } & \text { zo:-m-ər } & \text { 'summer' } \\ \text { teu-g } & \text { 'gulp' } & \text { teu-g-əl } & \text { 'rein' } \\ \text { hel-d } & \text { 'hero', } & \text { hel-d-ər } & \text { 'clear' } \\ \text { scham-p } & \text { 'graze' } & \text { scham-p-ər } & \text { 'scornful' } \\ \text { nor-m } & \text { 'norm' } & \text { mor-m-əl } & \text { 'freak' } \\ \text { wes-p } & \text { 'wasp' } & \text { kwis-p-əl } & \text { 'wag' } \\ \text { tek-st } & \text { 'text' } & \text { ek-st-ər } & \text { 'magpie' } \\ \text { pac-t } & \text { 'pact' } & \text { ac-t-ə } & \text { 'act' }\end{array}$

A number of additional remarks can be made on these issues.

First, note that all data with obstruent clusters above share three interesting constraints. Two of these were already explicitly mentioned in Zonneveld (1983), who noted, first, that obstruent clusters in underived words in Dutch are generally voiceless, and, second, that they do not exceed the number of two. In sum, they are subject to the restrictions depicted schematically in (19).

Restrictions for [voice] in obstruent(cluster)s

$\begin{array}{llll} & 0 & 00 & 000 \\ - \text { voice } & \mathrm{x} & \mathrm{x} & - \\ \text { +voice } & \mathrm{x} & - & -\end{array}$

Exceptions to these conditions are scarce, and are often loanwords. A voiced cluster of two is found in labda 'lambda' and Bagdad, but we have not found a voiced cluster of three. Marked voiceless clusters of three occur in tekst and ekster in (18), and words such as godzpe 'gudzpa', oogst 'harvest', and a few others. These conditions are relevant to (17) for two reasons. First, they explain the observational gap that if the appendix contains a dental obstruent cluster, the (free) second position of the rime cannot be filled by an obstruent itself (given a small handful of exceptions such as tekst). Second, they explain why the obstruent cluster appendix, if it is there, is always voiceless. Given (19), there is no need to burden our theory of the syllable with additional machinery to capture these facts. Independent of the contraint on [voice] is, furthermore, the apparent condition that in a cluster of obstruents one of them is always dental, in mirror image. 


$$
\text { *... [ } \left.{ }_{-\mathrm{cor}}^{-\mathrm{son}}\right]\left[\begin{array}{l}
-\mathrm{son} \\
-\mathrm{cor}
\end{array}\right]
$$

The loan Afghaan 'Afghan' is among the very few exceptions, and note that even the three marked obstruent clusters in tekst, and so on, have only one non-dental. We also assume that words like obstruent and extase 'ecstasy' contain Latin/Greek prefixes, synchronically motivatable as such.

Second, this view of the Dutch syllable is sufficiently restricted to expect various classes of exceptions. They come in various degrees of interest: some of them are only superficially exceptional, while others must be marked as irregular in the lexicon. At least three phonological rules are the source of surface exceptions to the bipositional rime restriction. Examples like pi(:)stool 'pistol' in (21a) led Trommelen (1983) to allow a tripositional rime for obstruents in third position. As far as we can see, however, these data result from the interference of a phonological rule (unknown to us from the literature) that lengthens (unstressed) $i$ before a dental cluster. Alternations such as those in (21b) support this view.

$\begin{array}{lllll}\text { a. } & \text { pi(:)stóol } & \text { 'pistol' } & \text { bi(:)stró } & \text { 'bistro' } \\ & \text { sy(:)stéem } & \text { 'system' } & \text { pi(:)stáche } & \text { 'pistachio' } \\ \text { b. } & \text { regíster } & \text { 'register' } & \text { regi(:)stréren } & \text { 'to register' } \\ \text { magíster } & \text { 'master' } & \text { magi(:)stráal } & \text { 'masterly' } \\ & \text { miníster } & \text { 'minister' } & \text { mini(:)stérie } & \text { 'ministry' }\end{array}$

Note also the near-minimal pair pi(:)stáche vs. pastiche. Examples such as symptoom 'symptom', plank-ton, plant-soen 'park', and rant-soen 'ration' were cited by Trommelen as further support for the tripositional rime. One particular aspect of these data, however, suggests a different analysis. The obstruent in third position is never a fricative (*symf-toon, *derg-soen), from which it follows that these data had better be looked upon as the outputs of a rule inserting an epenthetic plosive in between a syllable-final nasal and a dental obstruent, assuming underlying forms such as /sym-toom/, /plan-ton/, and /plan-soen/. Finally, a third phonological rule appears to be available for cases like monstrans, minstreel, and Australië, the internal -str- of which cannot be accommodated by our template, after an XX-rime. The way out here is as follows. Trommelen (1983) proposes the filter in (22) to account for the absence of $s r-, z r-, \check{s} r$-, and $\check{z} r$-(vs. $\sqrt{ } t r$ - and $d r$-in onset position either word-internally or word-initially:

$$
\left.*\left[\begin{array}{l}
+ \text { cor } \\
+ \text { cont }
\end{array}\right] \mathrm{r}\right]_{\text {Onset }}
$$

At the same time, she notes that word-initially this does not stop $s r$-, since left-extrametrical $s$ - (recall (9), (10)) should be able to combine with the independently possible onset $r$-. As there is no revealing way to avoid this effect of the otherwise abundantly motivated extrametrical $s$-, she proposes

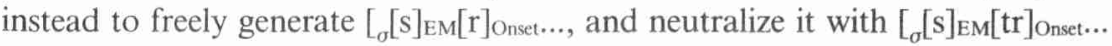


by a rule of $t$-epenthesis between (extrametrical) $s$ and $r$. This rule finds a small amount of support through alternating forms such as those in (23), noted in Zonneveld (1983):

$\begin{array}{llll}\text { waaien } & \text { 'to blow' } & \text { z-waaien } & \text { 'to wave' } \\ \text { wenken } & \text { 'to motion' } & \text { z-wenken } & \text { 'to turn' } \\ \text { loom } & \text { 'slow' } & \mathrm{s} \text {-loom } & \text { 'lethargic' } \\ \text { rekken } & \text { 'to pull' } & \mathrm{s}[\mathrm{t}]-\text { rekken } & \text { 'to stretch' } \\ \text { remmen } & \text { 'to brake' } & \mathrm{s}[\mathrm{t}]-\mathrm{remmen} & \text { 'to obstruct' } \\ \text { reep } & \text { 'string' } & \mathrm{s}[\mathrm{t}]-\mathrm{reep} & \text { 'line' }\end{array}$

A (minor) $s$-prefix appears to be voiced in Dutch before $w$, and turned into $s t$ - before $r$. It seems plausible to extend this analysis to the $s t r$-onset of the monstrans type of case, deriving it from underlying $s r$ - by epenthesis. For this to be possible, filter (22) must be reformulated so as to block šr- and $\breve{z r}$ - only, which can be done by replacing [ + cor] in $(22)$ with [ + high]. Excluding $z r$ - will be superfluous, since after epenthesis of $t$ the cluster will obtain its unmarked voiceless shape.

A special treatment, which we will not develop here, will be required for the long vowel [u:], which occurs in heavy internal rimes in a fair number of examples:

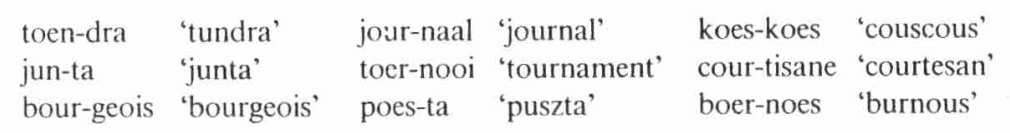

These cases are worth more detailed examination against the observation that [u:] is the only long vowel in the Dutch vocalic system without a short counterpart, while as a high vowel, it tends towards phonetic shortness (Smith 1973, Zonneveld 1978:39ff). Furthermore, although we cannot show this here for each single case, we expect that a morphological analysis may do away with the heavy rimes of cases such as bauk-siet 'bauxite', hyp-nose 'hypnosis', sculp-tuur 'sculpture', pleis-toceen 'Pleistocene', part-ner 'partner', ord-ner 'file', oor-log 'war', and arg-waan 'suspicion'. Insofar as these cases are morphologically derived, they would have to conform to the Right Hand Head Rule for Dutch (Trommelen and Zonneveld 1986, after Williams 1981), which says, among other things, that gender is determined by suffixes and righthand members of compounds. Thus, (de) argwaan would be non-neuter because (de) waan 'delusion' is, and so forth.

Thus, most of the surface evidence against a bipositional rime in the Dutch syllable appears to yield to some sort of reanalysis, some of it smoothly, some of it more preliminarily. Even after this, of course, a number of tedious cases will continue to exist, such as Sans-kriet 'Sanskrit', lorg-net 'pince-nez', and a few others, but the supporting evidence for a restricted view on the form of the Dutch syllable seems to us overwhelming when compared to this small handful.

Finally, perhaps the most interesting set of exceptions to (17) is the relatively 
small group of data in (25), well known from the literature; here, in spite of our discussion so far, long vowels (or generally, VX) appear before clusters with a non-dental, although there is always one dental in conformity with (20), which is, moreover, systematically final:

$\begin{array}{lll}\text { naakt 'naked' } & \text { feeks } & \text { 'shrew' } \\ \text { hoofd 'head' } & \text { nurks 'gruf' } \\ \text { kreeft 'crab' } & \text { corps 'body' } \\ \text { reeks 'string' } & \text { biecht 'confession' }\end{array}$

At one stage of our analysis we experimented with a formulation of $\mathrm{App}_{1}$ as ... C $([+$ cor $])$... (i.e. one consonant, or one consonant followed by a dental), which would enable us to accommodate (25). Apart from the fact that examples like those in (25) are relatively scarce, one important observation argues against this: the examples of (25) cannot themselves be followed by schwa-initials; that is, Dutch words of the form *aak-ta... are completely out. The existence of (25), therefore, cannot be captured through a reformulation of our App ; more generally, it cannot be captured through the reformulation of template (17) to the left of $\mathrm{App}_{2}$. The reformulation must therefore take place in $\mathrm{App}_{2}$ itself, where we propose to add a [+cor] obstruent position to cover (25). Notice also that historically several of these words do have a schwa-initial; compare naakt with its English gloss, hoofd with Middle Dutch hoved, and corps with its Latin source.

Additional evidence for this move comes from a larger group of words in which VX appears before a dental cluster of which the first is a sonorant, but again these clusters cannot generally be followed by schwa. (26) gives a number of these cases.

$\begin{array}{llllll}\text { beeld } & \text { 'image' } & \text { griend } & \text { 'holm' } & \text { taart } & \text { 'cake' } \\ \text { naald 'needle' } & \text { maand } & \text { 'month' } & \text { oord } & \text { 'place' } \\ \text { eelt } & \text { 'callus' } & \text { vriend } & \text { 'friend' } & \text { jaloers } & \text { 'jealous' } \\ \text { biels 'board' } & \text { grijns } & \text { 'smile' } & \text { stuurs } & \text { 'sullen' }\end{array}$

At first sight, it might be thought that these cases can be accommodated easily by extending the (two) dental obstruents of $\mathrm{App}_{1}$ to non-obstruents as well, but again, of course, the true test lies in the acceptability of schwainitials after these clusters. We find that examples like those in (26) are relatively plentiful, while only a very small number of schwa-ful words exist, such as aarde 'earth' and pienter 'clever'. This rather forceful bias follows if $\mathrm{App}_{1}$ is left unchanged and $\mathrm{App}_{2}$ contains a dental position, as proposed.

We will not extend our analysis to include those sporadic (three or four) cases mentioned in the literature where long vowels precede two dental sonorants, such as hoorn 'horn', toorn 'anger', and voorn 'roach'. For many, if not most, speakers, these are spelling forms only, which are actually pronounced bisyllabically with schwa, hoorn then being ambiguous with horen 'to hear', toorn with toren 'tower', and voorn with voren 'in front'. Moreover, the naakt/beeld pattern appears to be productive in the sense that it can be 
enlarged with new words (luuks 'luxurious', board, stoned), but the hoorn type typically lacks this ability, which is another indication of its irregularity. Also remaining outside the scope of our template is a very small residue of words (again, hardly more than three or four; see Trommelen 1983:69) which lack a final dental in a naakt-type word: twaalf 'twelve', bruusk 'blunt', and the loan schmi(:)nk 'to make up'; these will remain exceptions as well.

Thus, we conclude that the Dutch rime is in fact bipositional, that it may be followed by two appendices, that $\mathrm{App}_{1}$ may contain one (free) consonant or two dental obstruents, and that these may be followed, in $\mathrm{App}_{2}$, by one of the schwa-initials, or another dental. In the face of these results, we conclude also that perhaps the most appropriate view of $\mathrm{App}_{1}$ is the one suggested to us by Wim de Haas, who proposes that $s t$ and $t s$ in this position seem to function, simply, as one consonant. No doubt the fact that the members of these clusters share almost completely the usual phonological feature matrix, except for [continuant], adds support to this proposal. While we recognize the plausibility of this idea, we will also, in section 2.3 below, present facts suggesting a certain degree of independence between the (a) and (b) branches of $\mathrm{App}_{1}$ in (17): the range of contexts for the dental cluster is relatively restricted as compared to that of the free consonant. With this proviso, we now reformulate the template of (17) as (27).

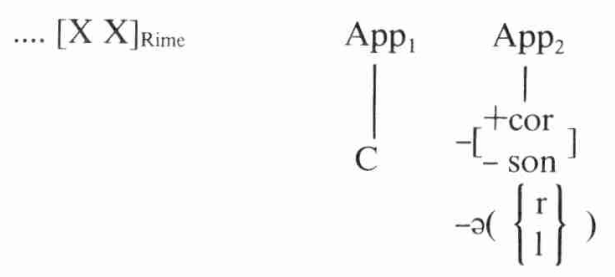

\subsection{Sonority}

One of the key observations that our analysis so far intends to express is that schwa-initials can be added freely to "existing" words. That is, if Dutch allows extra possibilities for its syllables at the right-hand word-edge, expressed as our $\mathrm{App}_{1}$, schwa-initials can be added even outside that, expressed as our $\mathrm{App}_{2}$. In principle, the consonant of $\mathrm{App}_{1}$ is free, i.e. it can be a sonorant or an obstruent (or a dental cluster "behaving as" a single (obstruent) consonant). One of the most interesting constraints on this free addition, however, is that it may never result in a violation of the sonority hierarchy, which says that in a syllable sonority decreases inside out and, most pertinent to our case, that in a rime sonority decreases rightward. Thus, held, norm, and pact in (28) all conform to this principle, but especially *hedl, with its sequence of obstruent-sonorant is out. There appears to be a plausible way to express this insight within our analysis (see (28)), profiting maximally from the universality of the sonority hierarchy by a minimum of language-specific means. 
(28)

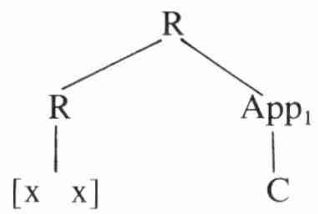

If this is the correct way of looking at things, it is interesting to note that our analysis now provides an interesting prediction, completely unknown to us from the literature, but which seems to conform to the data to a highly interesting degree:

(29) Clusters before schwa conform to the sonority hierarchy (left-to-right), while those before full vowels need not.

Naturally we cannot here illustrate fully the extent of the prediction in (29) for all possible consonant clusters of Dutch, but we will provide a number of examples of this claim in order to demonstrate what is going on. First, notice from (30) that, just as in English, $t r$ - is allowed as a Dutch onset (internally, but also initially; cf. traan 'tear', trui 'sweater', and so on), while $t$ - is not (*taan, etc.). Internally, the latter is broken up in the middle, and the vowel preceding it is short in order to conform to the bipositional rime.

$\begin{array}{llll}\text { ka:-trol 'pulley' } & \text { alba:-tros 'albatross' } & \text { at-las 'atlas } \\ \text { pa:-trijs 'partridge' } & \text { an-traciet } & \text { 'anthracite' } & \text { at-leet 'athlete' } \\ \text { vi:-trage 'curtain' } & \text { por-tret } & \text { 'portrait' } & \text { Bet-lehem 'Bethlehem' } \\ \text { ci:-troen 'lemon' } & \text { oc-trooi } & \text { 'patent' } & \text { med-ley 'medley' }\end{array}$

Our analysis now predicts that similar data cannot exist with schwa as the vowel after the syllable break. In order to see this, consider the fact that of a hypothetical pair such as $k a$ :-trol $/ * k a$ :-tral our analysis predicts the possible existence of the former by simple "concatenation" of two separately possible syllables, but the latter must be out, since the internal -tr-cluster cannot be accommodated within $\mathrm{App}_{1}$ (this is another good reason to limit the lower branch dental cluster in $\mathrm{App}_{1}$ specifically to obstruents, as argued earlier). The case of at-las/*at-las, however, is very different. The former is again a concatenation of two possible syllables, but this time the latter could be captured by our template: $a t$ - as a rime, $-l$ - as a free (single) consonant, and -əs as a schwa-initial. Yet, cases like *at-los are just as unacceptable as *ka:-trol, a fact we would like to predict rather than treat as a coincidence. Precisely this prediction follows if $\mathrm{App}_{1}$ is subjected to the sonority hierarchy, as forced by (28): neither type can be accommodated if the scope of the sonority hierarchy is extended to $\mathrm{App}_{1}$, as in (31). 


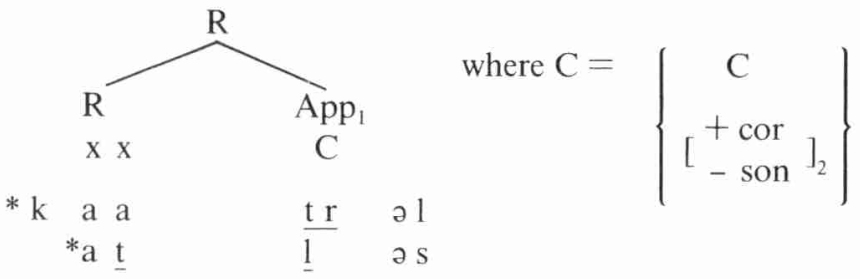

We know of only one surface exception to (31) among the $t$ - onset cases, the loan butler. For Modern Dutch this case may be explained away as an example of the productive Agent -er suffix of help-er 'assistant', and so forth, following a root. Analyses of this type must be available anyway, for example in order to be able to describe verbs like stagn-eren 'stagnate', in which -eer is a very productive verbalizing suffix, whereas stagn-by itself clearly violates the sonority hierarchy. Again, this may be a root. Among the tr- onsets we have not come across a single exception to the ${ }^{*} X X$-tra constraint, against at least 15 to 20 regular cases à la katrol, with a full vowel following the cluster. This appears to support our proposals in a highly suggestive manner.

As a second example towards the same conclusion, consider the velar fricative y, before nasals. Since nasals are out from second onset position by the C(L) onset template, we predict that these clusters will be preceded by short vowels, which is empirically correct. Moreover, our analysis also predicts that these clusters cannot be followed by schwa, since $\mathrm{r} N$ - violates the sonority hierarchy. In (32) we give the supporting evidence for this, noting that drach-me 'drachma' is the only counterexample we know of.

$$
\begin{array}{lllll}
\text { ag-naat } & \text { 'agnate' } & \text { pig-mee } & \text { 'pygmy' } & \text { stig-ma 'stigma' } \\
\text { mag-neet } & \text { 'magnet' } & \text { dog-ma } & \text { 'dogma' } & \text { sig-ma 'sigma' } \\
\text { mag-nolia } & \text { 'magnolia' } & \text { fleg-ma 'phlegm' } & \text { mag-ma 'magma' } \\
\text { cog-nitie } & \text { 'cognition' } & \text { ach-med 'Achmed' } & &
\end{array}
$$

The cluster -sm- behaves in much the same fashion (jas-mijn 'jasmin', kosmos 'cosmos'), except for an interesting exception: the nominalizing suffix -isme, with schwa after the counter-sonoric -sm- cluster. Of course, marking this suffix as an irregularity would rid us of it in one sweep, but in this case there may be more phonology behind its behavior than meets the eye: -isme is one of two suffixes of an '- $\mathrm{iC}_{0}$ ' shape, and both are irregular. -isme- violates the sonority hierarchy with its internal cluster, and geographic -ië- [i:ja] is odd as well: it is the only Dutch suffix in which schwa follows a vowel (otherwise *Va is unexceptional for Dutch). We propose that these oddities be explained by giving both suffixes an underlying full vowel, say $a$. A rule (of allomorphy) changing $a$ to $ə$ in suffixes of this type will then account for their irregular surface forms. 
Thirdly, note that surface violations of our template may be due simply to independent constraints of the language. Thus, the relatively frequent occurrence of internal $-n j$ - and $-l j$ - both before full vowels and before schwa (see (3)) appears to indicate that in Dutch these clusters do not by themselves constitute violations of the sonority hierarchy; nevertheless, final $-n j$ and $-l j$ are completely out.

$\begin{array}{llll}\text { ban-jo 'banjo' } & \text { oranje } & \text { 'orange' } \\ \text { ran-ja 'orangeade' } & \text { franje } & \text { 'frills' } \\ \text { lasag-na 'lasagna' } & \text { kanjer } & \text { 'whopper' } \\ \text { vig-net 'vignette' } & \text { campagne } & \text { 'campaign' } \\ \text { gal-joen 'galleon' } & \text { medalje } & \text { 'medal' } \\ \text { pal-jas 'clown' } & \text { rapalje } & \text { 'riff-raff' }\end{array}$

The reason for the absence of final $-n j$ and $-l j$ becomes clear if we realize that $j$ is also absent finally after long vowels. Thus the correct constraint on $j$ excludes it as a final consonant, allowing for the data in (33) (for further discussion see Trommelen 1983:145ff).

We could go on to demonstrate the operation of our restricted view of the Dutch syllable with regard to further clusters, but the impact of these examples would not differ greatly from the above: (29) holds for Dutch, and (28) strikes us as the best way to formalize it. Further evidence comes from different quarters, therefore. In particular, Stroop (1981) discusses a phenomenon of metathesis affecting words ending in -sp, such as gesp 'buckle' and wesp 'wasp', producing geps and weps. This phenomenon occurs sporadically and semi-humourously in the standard language, but is much more common in southern dialects. The most noteworthy aspect of Stroop's findings, however, is that in those dialects where metathesis is regular, words with schwa such as mispel 'medlar' undergo the rule as well, being changed to mipsel. This would be hard to grasp if the syllable break were in the middle of the cluster in these words. In our analysis the internal $-s p$ - cluster before schwa has precisely the same status as final $-s p$, and this appears to rationalize the process in a way that no competing analysis seems to be capable of.

With the template in (28) as the result of our analysis, we are now in a position to readdress the four filters formulated in a rather crude form in (5).

We consider it further evidence for our proposals that they enable us to do away with the amalgamations of braces, parentheses, boundaries, schwas, and non-schwas in these filters, with favorable results: we are left with no details other than those pertaining to the specific sound segments involved. Below, we repeat the filters from (5) on the left, and add the new versions on the right.

$$
\left.h \text {-filter: } \quad * \mathrm{~h}\left\{\begin{array}{c}
\mathrm{C} \\
\# \\
\partial
\end{array}\right\} \quad * \mathrm{~h}\right]_{\text {Rime }}
$$




$$
\begin{aligned}
& \text { r-filter: } \left.\quad * \mathrm{~V}_{\mathrm{i}} \mathrm{V}_{\mathrm{j}} \mathrm{r}\left\{\begin{array}{c}
\mathrm{C} \\
\# \\
\partial
\end{array}\right\} \quad * \mathrm{~V}_{\mathrm{i}} \mathrm{V}_{\mathrm{j}} \mathrm{r}\right]_{\text {Rime }} \\
& \left.\left.n g \text {-filter: } \quad * \eta\left\{\begin{array}{l}
x \\
\chi
\end{array}\right\} \begin{array}{l}
C_{\#} \\
a
\end{array}\right\} \quad * \eta\left\{\begin{array}{l}
x \\
\chi
\end{array}\right\}\right]_{\text {Rimi }} \\
& \text { ฤ-filter: } \quad * \eta V(\text { for } V \neq a) \quad *[\sigma]
\end{aligned}
$$

\subsection{Some further observational facts}

In section 2.1 above we discussed the proposal that our App $\mathrm{p}_{1}$ contain a single (free) consonant only, and that the dental obstruent clusters -st-and - $t s$ - act as single consonants in also being possible instances of this appendix. Accepting this tentatively, we also suggested that the single consonant and the obstruent clusters nevertheless behaved as independent branches of this appendix. In this section we will review the evidence for this, noting also that most of the data discussed contribute to our view of the Dutch rime as allowing only two positions which can be elaborated at the right-hand word-edge by appendices.

With this in mind, let us observe that so far we have discussed extensively only three instances of schwa-initial $\mathrm{App}_{2}$ : $-e r$, $-e l$, and $-e$. Examples can be found in (11)-(13) and (18), and reviewing this material it is likely to occur to the reader that the schwa-initial "outer appendix" -er is (much) more frequent than its two cousins after the dental obstruent cluster, while all three are more or less equally frequent after the free consonant (again, this is a fact of Dutch syllable structure that has hitherto gone unnoticed, as far as we are aware). Although we might trouble ourselves to incorporate this gradual difference into our analysis, it appears to be much more interesting to observe that, besides these gradual differences, there are also systematic ones if we consider further schwa-initials in addition to the three mentioned. They fall into two groups: one group can only follow the free consonant and does not occur after dental obstruent clusters, the other may occur after neither of these branches. Examples of the former are given in (35), examples of the latter in (36).

$\begin{array}{llllll} & \text {-ən } & & \text {-əm } & \text {-əs } \\ \text { wapen } & \text { 'weapon' } & \text { bezem } & \text { 'broom' } & \text { gratis } & \text { 'free' } \\ \text { baken } & \text { 'beacon' } & \text { bodem } & \text { 'bottom' } & \text { vonnis } & \text { 'judgment' } \\ \text { zegen } & \text { 'blessing' } & \text { bliksem } & \text { 'lightning' } & \text { kermis } & \text { 'fun fair' } \\ \text { oefen } & \text { 'exercise' } & \text { goochem 'clever' } & \text { dreumes } & \text { 'toddler' } \\ \text { teken } & \text { 'sign' } & \text { adem } & \text { 'breath' } & \text { stennis } & \text { 'trouble' }\end{array}$


(36)

$\begin{array}{llllll} & \text {-ək } & & \text {-uw } & & \text {-a... } \\ \text { havik } & \text { 'hawk', } & \text { schaduw } & \text { 'shadow' } & \text { wereld } & \text { 'world' } \\ \text { monnik } & \text { 'monk' } & \text { zenuw } & \text { 'nerve' } & \text { arend } & \text { 'eagle' } \\ \text { perzik } & \text { 'peach' } & \text { zwaluw } & \text { 'swallow' } & \text { mosterd } & \text { 'mustard' } \\ \text { hinnik } & \text { 'neigh' } & \text { peluw } & \text { 'pillow' } & \text { mieters } & \text { 'super' }\end{array}$

\begin{tabular}{lllll} 
& \multicolumn{1}{c}{-at } & -əf & -əp \\
lemmet 'blade' & tinnef & 'garbage' & hennep & 'hemp' \\
pocket 'paperback' & sherriff & 'sheriff & & \\
ticket 'ticket' & & & \\
racket 'racket' & & &
\end{tabular}

These examples have phonetic schwa in their final syllables, except for those ending in $-u w$, which have [üw]. Trommelen (1983:33-4) points out, however, that the irregular stress properties of these words (stress on the pre-final syllable rather than on "strong" "ü, as in minúut 'minute', kostúum 'suit', figúur 'figure') can be explained if the final syllable contains schwa, which cannot be stressed. Furthermore, in her account the phonetic shape of $-u w$ turns out to be independently derivable in Dutch phonology by the rounding branch of a rule that raises schwa before velars. Thus, we conclude that there is a tripartite division among Dutch schwa-initials, given their ability or disability to occur after the respective two branches of our $\mathrm{App}_{1}$ :

$$
\begin{aligned}
& \mathrm{App}_{1} \text { (a) C: schamp-er (18) morm-el (18) sect-e } \\
& \text { (b) dentals: lijst-er (11) borst-el (11) bust-e } \\
& \mathrm{App}_{1} \text { (a) C: wap-en grat-is schad-uw (35) } \\
& \text { bez-em hav-ik wer-eld } \\
& \text { neither: tick-et tinn-ef henn-ep (36) }
\end{aligned}
$$

These data are interesting from another point of view as well. It had occurred to us at one point (and been suggested to us independently at another) that schwa is apparently not preceded in Dutch by the usual C(L) onset, but only $\mathrm{C}$ (or the dental cluster), and that this, in combination with the fact that $-e r$ and $-e l$ are among the most frequent schwa-initials, might indicate the effect of a rule of "metathesis", applying to underlying representations such as /sxampra/ for schamper to reverse the order of the final two segments, thereby explaining the absence of these onsets before schwa-initials. Such an analysis may or may not be plausible on historical grounds (and in fact a very small residue exists in the language where the French origin has persisted in surface violations of our analysis: oeuvre, libre, manoeuvre, and ensemble, with obvious glosses), but the metathesis analysis for the regular cases appears to run into grave difficulties as soon as one realizes that "bare" schwa seems to be subject to the same conditions as $-\mathrm{el}$ and $-\mathrm{er}$ and that, moreover, all schwa-initials of (35)-(36) have similar left-hand constraints; thus, one looks in vain for final syllables like -plon, $-k r ə k$, and -vrof. Even more seriously, a metathesis analysis for all schwa-initials would introduce a host of onsets completely unknown elsewhere, such as (waa-)pno and (aa-)dmo. These 
observations clearly remove the foundation from under a metathesis analysis of the facts presented here, and an explanation along these lines does not seem plausible to us .

Just as schwa-initials may put constraints on the phonological material that can occur before them, one may also imagine particular sound segments to do so from the inside out: rime material may prefer one of the branches of $\mathrm{App}_{1}$ as its right-hand neighbor, and our analysis predicts that this will be the case whether or not schwa follows. A striking case in point appears to be the behavior of the diphthong [au], which cannot occur before (final) $r$ as a result of one of the constraints of (34), but which is also constrained in the way intended here: it can be followed by a single consonant only, wordfinally as well as before schwa, that is, neither ..*aust nor ..*austo occur (with the German loan Faust as the only exception we know of):

$\begin{array}{llllll}\text { fauna } & \text { 'fauna' } & \text { faun } & \text { 'faun' } & \text { fraude } & \text { 'fraud' } \\ \text { aurora } & \text { 'aurora' } & \text { paus } & \text { 'pope' } & \text { pauze } & \text { 'pause' } \\ \text { trauma } & \text { 'trauma' } & \text { applaus } & \text { 'applause' } & \text { pauper } & \text { 'pauper' } \\ \text { auto } & \text { 'motorcar' } & \text { koud } & \text { 'cold' } & \text { klauter } & \text { 'climb' } \\ \text { aureool } & \text { 'halo' } & \text { schout } & \text { 'bailiff' } & \text { schouder } & \text { 'shoulder' } \\ \text { saucijs } & \text { 'sausage' } & \text { pauk } & \text { 'kettledrum' } & \text { louter } & \text { 'mere' }\end{array}$

Finally, our key notion of the bipositional rime itself receives support from various observations about Dutch. We mention two of them. First, vowelfinal Greek prefixes like pro-, bio-, dia-, and auto- display an alternation of vowel length in closed vs. open syllables which makes sense against the background of the theory of the Dutch syllable defended here. In this respect, consider the data in (39).

\begin{tabular}{|c|c|c|c|}
\hline $\begin{array}{l}\text { autop(-)sie } \\
\text { autoch(-)toon } \\
\text { vs. }\end{array}$ & $\begin{array}{l}\text { ‘autopsy' } \\
\text { 'autochthonous' }\end{array}$ & $\begin{array}{l}\text { pros(-)pectus } \\
\text { prog(-)nose } \\
\text { vs. }\end{array}$ & $\begin{array}{l}\text { 'prospectus' } \\
\text { 'prognosis' }\end{array}$ \\
\hline $\begin{array}{l}\text { auto(:)-noom } \\
\text { auto(:)-craat }\end{array}$ & $\begin{array}{l}\text { 'autonomous' } \\
\text { 'autocrat' }\end{array}$ & $\begin{array}{l}\text { pro(:)-loog } \\
\text { pro(:)-gramma }\end{array}$ & $\begin{array}{l}\text { 'prologue' } \\
\text { 'program' }\end{array}$ \\
\hline $\begin{array}{l}\text { bios(-)coop } \\
\text { diag(-)nose } \\
\text { vs. }\end{array}$ & $\begin{array}{l}\text { 'movies' } \\
\text { 'diagnosis' }\end{array}$ & $\begin{array}{l}\text { res(-)pect } \\
\text { parag(-)nost } \\
\text { vs. }\end{array}$ & $\begin{array}{l}\text { 'respect' } \\
\text { 'clairvoyant' }\end{array}$ \\
\hline $\begin{array}{l}\text { bio(:)-loog } \\
\text { dia(:)-gram }\end{array}$ & $\begin{array}{l}\text { 'biologist' } \\
\text { 'diagram' }\end{array}$ & $\begin{array}{l}\text { re(:)-sistent } \\
\text { para(:)-plu }\end{array}$ & $\begin{array}{l}\text { 'resistant' } \\
\text { 'umbrella' }\end{array}$ \\
\hline
\end{tabular}

Second, for those fond of what is sometimes called "external" evidence for our theory of the bipositional rime, we note, as one further set of data, a recent list of medical brand names we happened to come across in Bloem and Wolffers (1985). As is well known, medical terminology strikes one as highly complex and fortuitous at first sight, but it is therefore also a fruitful testing ground for phonological intuitions (see also Siegel (1974:139-42) for intuitions about English stress based on such data). Thus, we observe that 
the list below of sometimes suggestive, but sometimes also uninterpretable, medical brand names contains not a single violation of our proposals on the Dutch syllable:

agedal, alival, anafranil, imipranine, concordin, evadyne, insidon, limbitrol, linostil, mutabon, nortriptylin, noveril, tofranil, trausabun, tryptizon, ludiomil, pretrofan, quitanox, sarotex, sensaval, sinequan, surmontil

We leave it to the reader to provide the hyphens, but in doing so (s)he will note especially that all internal rimes are bipositional, and that tripositional rimes occur in word-final position only, as predicted.

\section{STRESS}

Traditionally, the accentual behavior of Dutch schwa is viewed simply as the impossibility for it to receive (main) stress at the word level. This property of schwa has been expressed in the literature (Schultink 1977, 1980) by providing schwa lexically with the feature [Unstressable]. This undeniably captures the observation, but at the same time overlooks a more fundamental characteristic of schwa from which the above follows naturally: main stress in Dutch is immediately before schwa. Of course, there is no empirical difference between these claims for either monosyllabic (héld, slóom, fáun) or bisyllabic (schámper, mórmel, sécte) words, but the difference comes to light in longer words, where schwa clearly exhibits its "stress-attracting" character.

$\begin{array}{llll}\text { theáter } & \text { 'theater' } & \text { synagóge } & \text { 'synagogue' } \\ \text { siníster } & \text { 'sinister' } & \text { helicópter } & \text { 'helicopter' } \\ \text { kalénder } & \text { 'calendar' } & \text { salamánder } & \text { 'salamander' } \\ \text { pantóffel } & \text { 'slipper' } & \text { pyramíde } & \text { 'pyramid' } \\ \text { komkómmer } & \text { 'cucumber' } & \text { trampolíne } & \text { 'trampoline' } \\ \text { kanúnnik } & \text { 'canon' } & \text { dromedáris } & \text { 'dromedary' }\end{array}$

In itself, pre-final stress is not transparently typical of Dutch. First, more often than not, antepenultimate stress is found before pre-final $i$, but still prefinal $i$ is stressed before schwa.

$\begin{array}{llll}\text { rádio } & \text { 'radio' } & \text { machíne } & \text { 'machine' } \\ \text { álibi } & \text { 'alibi' } & \text { kalíber } & \text { 'calibre' } \\ \text { káriboe } & \text { 'caribou' } & \text { elíte } & \text { 'elite' } \\ \text { líbido } & \text { 'libido' } & \text { pyramíde } & \text { 'pyramid' } \\ \text { harmónica } & \text { 'harmonica' } & \text { artíkel } & \text { 'article' }\end{array}$

Second, as noted above, final stress typically occurs on sufficiently heavy syllables, either of the -VVC or -VCC type: 


$\begin{array}{llll}\text { kos-túum } & \text { 'suit' } & \text { garni-zóen 'garrison' } \\ \text { to-néel } & \text { 'stage' } & \text { feno-méen 'phenomenon' } \\ \text { spe-lónk } & \text { 'cave' } & \text { kara-bíjn } & \text { 'carbine' } \\ \text { ce-mént } & \text { 'cement' } & \text { basi-liek 'basilica' } \\ \text { da-mást } & \text { 'damask' } & \text { hya-cýnt 'hyacinth' }\end{array}$

Third, for pre-final open syllables stress may be either on the penult or on the antepenult:

$\begin{array}{llll}\text { diplóma } & \text { 'diploma' } & \text { pérgola } & \text { 'pergola' } \\ \text { tornádo } & \text { 'tornado' } & \text { fárao } & \text { 'pharaoh' } \\ \text { ravióli } & \text { 'ravioli' } & \text { bróccoli 'broccoli' } \\ \text { pijáma } & \text { 'pyjamas' } & \text { pánama 'Panama' } \\ \text { torpédo } & \text { 'torpedo' } & \text { tómbola } & \text { 'tombola' }\end{array}$

Pre-final stress, finally, is a consistent property of closed pre-final syllables. This holds also for 'double spelling consonants', which although phonetically single and intuitively part of the onset of the final syllable rather than the coda of the pre-final, count as pre-final VC for stress. This is predicted, of course, by our requirement that the rime of any syllable be XX:

$\begin{array}{ll}\text { aórta } & \text { dilémma } \\ \text { agénda } & \text { gorílla } \\ \text { fiásco } & \text { spaghétti } \\ \text { calýpso } & \text { esprésso } \\ \text { propagánda } & \text { regátta }\end{array}$

Thus, VXC is clearly sufficiently (super-)heavy to bear main stress in final position. Comparing VC and VV, we see that VC counts as heavy as well, being exceptionlessly "opaque" in pre-final syllables; VV appears to be relatively weak, since it is insufficiently heavy to consistently carry main stress pre-finally. Perhaps words with pre-final VV (other than $i$ ) are simply marked for stressclass membership in order to force this distribution (see also below). This weight difference between VC and VV is easily confirmed word-finally, where stressed VC is very frequent while stressed VV is scarce: barón 'baron', bordés 'steps', galóp 'gallop', and salmiák 'sel-ammoniac' vs. only a small number of recent loans, such as menú 'menu' and buró 'bureau' (as opposed also to (44)). Finally, schwa in the ultimate "attracts" main stress onto the preceding syllable, as in (41); we note additionally from these data that -VVa is out by a general constraint of Dutch on this sequence, well known from the literature (see above and Zonneveld 1978:71ff).

In order to capture these generalizations, we will assume here a framework of metrical stress-assignment as proposed for Dutch by Neyt and Zonneveld (1982) on the basis of Liberman and Prince (1977), elaborated within the more recent variant of Hayes (1982) according to proposals by Kager and Visch (1983), and with respect to syllable weight by Visch and Kager (1984) in particular. For a language like Dutch, this theory assigns stress to syllabic 
rimes, and rimes are assembled into feet. The cases of (43) are accounted for by making final VXC a monosyllabic foot. In the unmarked case, final $\mathrm{VV}$ is weak, which means that the data in (45) contain a binary branching final foot, with VC strong. The antepenultimate syllable is reached by marking the final rime of the pertinent words (as in (44)) as "stress-extrametrical", according to similar proposals for English by Hayes (1982); note the peripherality of this stress-extrametrical material. The feet thus created are then assembled into a word tree, with feet labeled $w / s$. We provide some examples in (46).
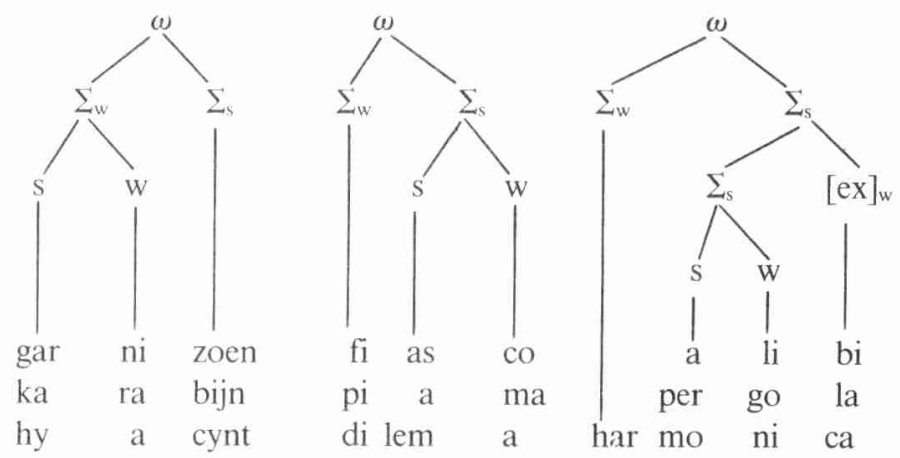

(46) is the result of the proposals for Dutch stress described above. Note also that, after a universal convention proposed by Hayes (1982), extrametrical elements are joined to a tree as weak sisters within the final foot. Besides giving one the opportunity to reach the third syllable from the right, the notion of extrametricality also gives one the opportunity, just as in English, to account for those few irregular cases where, in spite of heavy weight, stress is nonfinal, as in áltaar 'altar', ámbacht 'profession', and ólifant 'elephant'. If the final rimes of these words are stress-extrametrical, non-final stress follows by the rules of the language.

Focusing on the behavior of schwa, it will be clear that the most conspicuous aspect of this is its ability to force stress unexceptionally upon a pre-final rime projection. This is especially so for VV rimes (synagóge, etc. from (41)), since the VC rimes like those in sinister and legénde are easily captured by the independent generalization, necessary in any account of Dutch stress, that pre-final VC is strong enough to capture main stress independently of the quality of the vowel in the final rime. No such explanation, however, is available for pre-final VV, in view of the occurrence of pre-final stress on, e.g., torpédo, but antepenultimate stress in pérgola (see (44)). Thus, schwa seems to be an obligatory weak member of a final braching foot, whatever the preceding material. We agree that this is, eventually, the correct view of the behavior of schwa, but at the same time we are not aware of any analysis that does not simply postulate this, thereby avoiding the entire issue, without proposing other mechanisms devised especially for the situation at hand (see Van der Hulst 1984, and comments by Kager et al. 1985). We will show that the stress behavior of schwa does not require such ad hoc measures, but follows from a natural statement within our framework, about the status of the independently motivated schwa-initial Appendix 2 of template (27). 
Recall first of all that in section 2.2 we defined the level of adjunction for $\mathrm{App}_{1}$ as the rime, in order to get it within the domain of the sonority hierarchy. It will be obvious that the schwa-initials cannot be attached at this same level: containing a vocalic element, they would violate the sonority hierarchy if attached at the level of the rime. At the same time, as we have just seen, the schwa typical of $\mathrm{App}_{2}$ behaves in stress assignment as the weak branch of a binary branching foot. Furthermore, as depicted in the rightmost tree of (46), independently of the behavior of schwa the foot is also the level of adjunction of stress-extrametrical material. Therefore, the logical step to take within our analysis is not to say anything specific about schwa, but to specify $\mathrm{App}_{2}$ as stress-extrametrical. From this, all else follows without further stipulations: the level of adjunction is the foot, the status of schwa is $w($ eak), and stress is immediately before it. In order to see this, consider the following derivations.

(t)

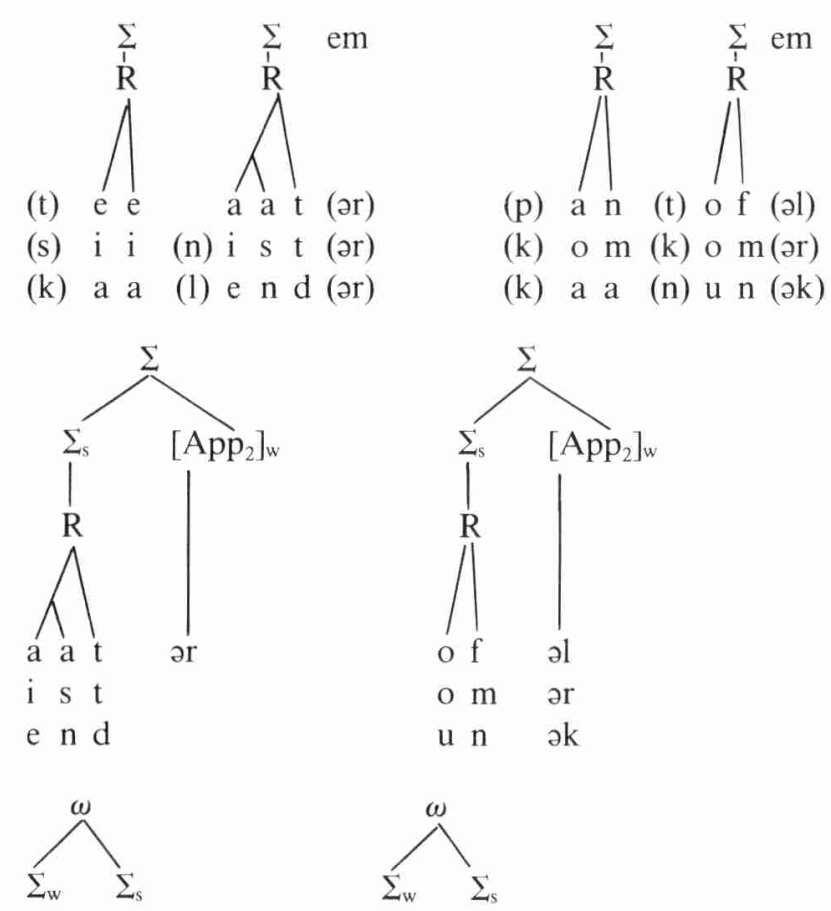

At the first stage of these derivations, rimes are created as "projections" for stress assignment. Normally, these rimes are bipositional, and this is what happens in the antepenultimate syllables. In the pre-schwa syllables, however, our independent syllable template forces the pre-schwa consonant into the preceding rime, as indicated. If, furthermore, on the basis of the stress properties of Dutch outlined above, VXC and VC are, to apply that term again, "opaque" for the stress rule counting leftward from the counting leftward from the right word-edge (are monosyllabic feet, or strong in a bisyllabic ( $s / w$ foot), the left-hand side of the intermediate representations follows. At this stage, stress- 
extrametrical schwa-initials $\left(\mathrm{App}_{2}\right)$ are attached as weak members at the foot level by Chomsky-adjunction, making their sisters strong by convention. Finally, the remaining syllables of these words are assembled into feet themselves, which are monosyllabic in each case of (47), but will be bisyllabic in examples such as $[\mathrm{sa}-\mathrm{la}]_{\Sigma}[\mathrm{mand}]_{\Sigma}-$-r and $[\mathrm{sy}-\mathrm{na}]_{\Sigma}[\mathrm{go}: \mathrm{g}]_{\Sigma}$-ə from (41). These feet are assembled into word stress, labeled $w / s$. In this way, then, we account for the discrepancy between torpédo vs. tómbola on the one hand, and obligatory pre-schwa stress in pyramíde and synagóge on the other: the VXC pre-schwa rimes of the latter are strong enough to capture main stress. Notice also that in this analysis we are able to explain in a principled manner why the pre-schwa stress pattern of Dutch should be completely exceptionless, as it is: although extrametricality as an exception device can be invoked for cases like áltaar (see above), marking final schwa in the same manner automatically blocks any other mark of this type to the left by Hayes's peripherality condition. Hence, weight cannot be violated to the left of schwa (*ál-taar-a), since the stess rules will be able to "read" only the word-final extrametricality mark on $\mathrm{App}_{2}$. This strikes us as very strong motivation to indeed explain Dutch pre-schwa stress through extrametricality, as proposed here.

Finally, observe that in itself, the particular structure of the pre-schwa rime does not follow from considerations of stress assignment, but was based on the syllable behavior of schwa, which is of course logically independent of stress. The fact that our syllable analysis leads to an explanation of otherwise curious stress data, however, strikes us as confirmation of the conclusions reached above concerning the syllable structure of Dutch, and its key notions of bipositional rime and right-peripheral appendices.

\section{CONCLUSION}

Our point of departure for this paper was the observation that superficially Dutch schwa seems to behave as a word boundary (\#). Both, in a sense, follow existing words. This was recognized as a syllable-sensitive phenomenon, especially so since we were able to formulate the restrictions on the occurrence of schwa as right-hand peripheral appendices, a notion independently available in linguistic theory in order to explain the observation that languages tend to allow excess syllable structure at the edges of domains, such as words. Exploring further the right-hand periphery of the Dutch syllable, we were led to the restriction that the Dutch rime is limited to two (obligatory) positions, $\mathrm{VX}$, where $\mathrm{X}$ is phonologically free (but non-null). Expressed in metrical terms, we would say that the Dutch rime is binary branching, labeled $s / w$. This is of course confirmed by the observation (also noted in Trommelen 1983) that Dutch has falling diphthongs, with left-hand stress: éi, úi, and áu. In this way, we succeeded in reducing the language-particular components of our analysis to the barest minimum, profiting maximally from independently motivated components of universal theory. Thus, taking schwa as a syllable appendix turned out to give us the opportunity to sketch an explanation for the stress behavior of this vowel, which is not always stressless, but in fact 
requires main word stress immediately before itself. We proposed that schwaful final syllables, being appendices, should be defined as stress-extrametrical, forcing them to be automatically adjoined as weak sisters to final feet into prosodic structure, creating patterns that explain the otherwise curious stress properties of schwa. In addition, we also explained through this move why weight violations of the áltaar type do not occur before schwa: the stress rules can only see the rightmost extrametricality mark on schwa, which therefore blocks any attempted stress shift to the right. In this way, our analysis of Dutch syllable structure in the first half of this paper plays a crucial role in the explanation of Dutch stress, together with a number of recent metrical universals, among which Halle and Vergnaud's notion of syllable appendix, and Hayes's peripherality condition on the application of stress rules.

We end this discussion with a brief typological speculation. To our mind, further research into the interaction of syllable structure and stress is not very likely to uncover a language similar to Dutch among its Germanic neighbors. A brief review of comparable phenomena shows that English is very different, at least in the "main stress before schwa generalization, as can be gathered by consulting (41). Furthermore, the intricacies of German schwa-insertion and -deletion (Strauss 1982, Van Lessen Kloeke 1981) make us seriously doubt the transferability of our observations to that language. Nevertheless, the fact that the mechanisms of our analysis are both intuitively and formally simple, and make a successful appeal to phonological universals at various points, demonstrates for us that Dutch may be relatively unique from a typological point of view, but not necessarily heavily marked. Furthermore, we are unaware of any rival analysis that correlates the relevant observations in the way proposed here, with a similar or superior explanatory range.

\section{REFERENCES}

Bloem, M. and I. Wolffers (1985) Hyperventilatie, Contact, Amsterdam.

Halle, M. and J.R. Vergnaud (1980) 'Three-dimensional phonology', Journal of Linguistic Research $1,83-105$.

Harris, J. (1983) Syllable Structure and Stress in Spanish, MIT Press, Cambridge, Mass.

Haugen, E. (1956) 'The syllable in linguistic description', in M. Halle, H.G. Lunt and H. McLean, eds., For Roman Jakobson, Mouton, The Hague, pp. 213-221.

Hayes, B. (1982) 'Extrametricality and English stress', Linguistic Inquiry 13, 227-276.

Hulst, H. van der (1984) Syllable Structure and Stress in Dutch, Foris, Dordrecht.

Hyman, L. (1984) A Theory of Phonological Weight, Foris, Dordrecht.

Kager, R., M. Trommelen and E. Visch (1985) Review article of Van der Hulst (1984), Spektator $15,123-138$.

Kager, R. and E. Visch (1983) 'Een metrische analyse van ritmische klemtoonverschijnselen', M.A. thesis, Instituut De Vooys, University of Utrecht.

Lessen Kloeke, W.U.S. van (1981) Deutsche Phonologie und Morphologie; Merkmale und Markiertheit, Niemeyer, Tübingen.

Liberman, M. and A. Prince (1977) 'On stress and linguistic rhythm', Linguistic Inquiry 8, 249336.

Neyt, A. and W. Zonneveld (1982) 'Metrische fonologie - de representatie van klemtoon in Nederlandse monomorfematische woorden', De Nieuwe Taalgids 75, 527-547. 
Schultink, H. (1977) 'Over de accentuering van afgeleide woorden in het Nederlands', in H. Heestermans, ed., Opstellen door Vrienden en Vakgenoten aangeboden aan Dr. C.H.A. Kruyskamp, The Hague, pp. 180-188.

Schultink, H. (1980) 'Boundaries, wordclasses, and the accentuation of derived words in Dutch', in W. Zonneveld, F. van Coetsem and O.W. Robinson, eds., Studies in Dutch Phonology, Nijhoff, The Hague, pp. 205-222.

Siegel, D. (1974) Topics in English Morphology, Doctoral dissertation, MIT, Cambridge, Mass. Smith, N.S.H. (1973) 'The phenomenon of d-deletion in Standard Dutch', Spektator 2, 421437.

Strauss, S.R. (1982) Lexicalist Phonology of English and German, Foris, Dordrecht.

Stroop, J. (1981) 'Metathesis van $s$ and p', Spektator 11, 224-248.

Trommelen, M. (1983) The Syllable in Dutch, Foris, Dordrecht.

Trommelen, M. and W. Zonneveld (1986) 'Dutch morphology: Evidence for the Right Hand Head Rule', Linguistic Inquiry 17, 147-169.

Visch, E. and R. Kager (1984) 'Syllable-weight and Dutch word stress', in H. Bennis and W.U.S. van Lessen Kloeke, eds., Linguistics in the Netherlands 1984, Foris, Dordrecht, pp. 197-205.

Williams, E. (1981) 'On the notions "lexically related" and "head of a word" , Linguistic Inquiry 12, 245-274.

Zonneveld, W. (1978) A Formal Theory of Exceptions in Generative Phonology, Foris, Dordrecht.

Zonneveld, W. (1983) 'Lexical and phonological properties of Dutch voicing assimilation', in M.P. van den Broecke, V.J. van Heuven and W. Zonneveld, eds. Sound Structure, Studies for Antonie Cohen, Foris, Dordrecht, pp. 297-312.

Zonneveld, W. and M. Trommelen, (1980) 'Egg, onion, ouch! On the representation of Dutch diphthongs', in W. Zonneveld, F. van Coetsem and O.W. Robinson, eds., Studies in Dutch Phonology, Nijhoff, The Hague, pp. 265-292.

Vakgroep Nederlandse taal-en letterkunde Rijksuniversiteit Utrecht

Trans 14

3515.JK UTRECHT

The Netherlands 